\title{
IGF-I stimulation of luteinizing hormone secretion, IGF-binding proteins (IGFBPs) and expression of mRNAs for IGFs, IGF receptors and IGFBPs in the ovine pituitary gland
}

\author{
C L Adam, T S Gadd ${ }^{1}$, P A Findlay and D C Wathes ${ }^{1}$ \\ Molecular Neuroendocrinology Group, Rowett Research Institute, Bucksburn, Aberdeen AB21 9SB, UK \\ ${ }^{1}$ Department of Veterinary Basic Sciences, The Royal Veterinary College, Boltons Park, Hawkshead Road, Potters Bar, Hertfordshire EN6 1NB, UK \\ (Requests for offprints should be addressed to C L Adam; Email: cla@rri.sari.ac.uk)
}

\begin{abstract}
Circulating concentrations of insulin-like growth factor-I (IGF-I) are reduced in juvenile sheep during nutritional growth restriction and the associated delay in puberty. Since exogenous IGF-I has been shown to stimulate luteinizing hormone $(\mathrm{LH})$ secretion, it is postulated that endogenous IGF-I may act as a stimulatory metabolic signal to the pubertal ovine hypothalamo-pituitary axis, yet its site of action is unknown. Using coronal hypothalamic and pituitary sections from pubertal ewe lambs, in vitro autoradiography was used to localise ${ }^{125}$ I-labelled IGF-I binding, and gene expression for components of the IGF system was localised by in situ hybridisation using oligonucleotide probes. High concentrations of ${ }^{125}$ I-IGF-I binding were seen in the pars tuberalis (PT) and pars distalis (PD) of the pituitary, and relatively little in the hypothalamus; binding in the PT but not the PD was displaced by excess unlabelled IGF-I. Large amounts of mRNA were detected for the type-1 receptor (IGF-1R) and for IGF-binding protein (IGFBP)-5, localised to the $\mathrm{PT}$ and $\mathrm{PD}$, and less intense specific hybridisation signals were obtained with mRNAs for IGF-II, type-2 receptor
\end{abstract}

(IGF-2R) and IGFBP-3. There was some evidence for specific hybridisation to IGFBP-4 mRNA in the PT. IGF-I, IGFBP-1 and IGFBP-2 mRNAs were not detected in PT and PD. None of the genes were expressed in hypothalamic tissue. Western-ligand binding on PD extracts from male castrates revealed by their molecular weights the likely presence of IGFBPs-2, -3 , and -5 . Finally, cultured PD cells from abattoir-killed sheep were challenged with IGF-I $(0 \cdot 1,1,10$ or $30 \mathrm{nM})$ or luteinizing hormone-releasing hormone (LHRH, $10 \mathrm{nM}$ ) alone, or both together. Basal LH output was stimulated by $10 \mathrm{nM}$ IGF-I $(120 \pm 11 \cdot 2 \%, \quad P>0 \cdot 05), 30 \mathrm{nM}$ IGF-I $(148 \pm 12 \cdot 8 \%, P<0 \cdot 01)$, and LHRH alone $(200 \pm 16 \cdot 1 \%$, $P<0 \cdot 001)$; there was no additive or subtractive effect of LHRH and IGF-I given together. Thus, an intrapituitary IGF system exists in sheep and the present results are consistent with an endocrine role for IGF-I in nutritional modulation of LH secretion at the level of the pituitary gland.

Journal of Endocrinology (2000) 166, 247-254

\section{Introduction}

It is postulated that insulin-like growth factor-I (IGF-I) is partly responsible for nutritional modulation of reproductive function in mammals. Circulating concentrations of IGF-I are elevated at puberty in rodents (Handelsman et al. 1987), primates (Mauras et al. 1996) and ruminants (Adam et al. 1995). Exogenous IGF-I administered to female rhesus monkeys by subcutaneous infusion accelerated puberty, probably by stimulating luteinizing hormonereleasing hormone (LHRH) neuronal activity (Wilson 1998); moreover, centrally administered IGF-I both stimulated LHRH output and significantly advanced puberty in rats, suggesting that IGF-I is a metabolic trigger for puberty, acting at the hypothalamic level (Hiney et al. 1996). However, an earlier study indicated that there may be fundamental species differences in the central distribution of receptors for IGF-I, since ${ }^{125}$ I-IGF-I binding was localised in the hypothalamic median eminence (ME) of rats, but in the pars tuberalis of the pituitary (PT) and not in the ME of sheep (Williams et al. 1995). It may therefore be unwise to extrapolate putative IGF-I feedback mechanisms between species. Furthermore, given their fundamentally different nutritional physiology, differences in central nutritional feedback between monogastric and ruminant species may perhaps be anticipated. IGF-I stimulation of luteinizing hormone $(\mathrm{LH})$ release from cultured anterior pituitary cells has been demonstrated for rats (Soldani et al. 1994) and pigs (Whitley et al. 1995), but not for a ruminant species.

In view of the observation that peripherally administered IGF-I can acutely stimulate LH secretion in sheep 
(Adam et al. 1997a), the objectives of the present studies were to determine in vitro whether its likely site of endocrine action on gonadotrophin secretion in this species is at the level of the hypothalamus or the pituitary gland. IGF-I mediates its effects through binding to a type-1 IGF receptor (IGF-1R) on target cells (LeRoith et al. 1995), where its actions are modulated by IGF-binding proteins (IGFBPs) (Jones \& Clemmons 1995). We therefore investigated ${ }^{125}$ I-IGF-I binding and gene expression for IGFs, their receptors and binding proteins along the ovine hypothalamo-pituitary tract. In addition, western-ligand binding was used to determine IGFBP activity in anterior pituitary homogenates. Lastly, since high concentrations of gene expression for components of the IGF system were found in the pituitary rather than the hypothalamus of this species, we sought to establish whether IGF-I induced LH release from ovine anterior pituitary cells in culture.

\section{Materials and Methods}

Tissue collection for in vitro autoradiography and in situ hybridisation

Brains and pituitary glands were obtained from four pubertal Suffolk $\times$ Greyface ewe lambs that had been reared on unrestricted food for another study (Adam et al. 1998). They were euthanised by lethal injection with sodium pentobarbitone (Euthesate, Willows Francis Veterinary, Crawley, UK) at 8 months of age. Postmortem examination of their ovaries revealed the presence of at least one corpus luteum, indicating that they had each initiated oestrous cyclicity and were in the luteal phase at death. Following decapitation, brains and attached pituitaries were rapidly removed, frozen in isopentane chilled over dry-ice, and stored at $-80{ }^{\circ} \mathrm{C}$. Coronal cryostat sections $(20 \mu \mathrm{m})$ of hypothalamic and pituitary tissue were cut, thaw-mounted onto slides double-coated with gelatin and poly-L-lysine, and stored at $-80^{\circ} \mathrm{C}$.

\section{In vitro autoradiography}

Recombinant human IGF-I (Bachem UK Ltd, Essex, UK) was iodinated and autoradiographic localisation of ${ }^{125}$ I-IGF-I binding sites was performed as described in detail previously (Williams et al. 1995). Briefly, paired sections were washed at $4{ }^{\circ} \mathrm{C}$ for $6 \mathrm{~min}$ in high-salt, low-pH buffer $(0 \cdot 2 \mathrm{M} \mathrm{NaAc}, 0.5 \mathrm{M} \mathrm{NaCl}$ with $0 \cdot 1 \%$ BSA, pH 3.5), in order to dissociate bound IGF-I, then washed for $20 \mathrm{~min}$ in $50 \mathrm{mM}$ Tris- $\mathrm{HCl}$ (pH 7.4 and containing $5 \mathrm{mM} \mathrm{MgCl}_{2}$ ). They were then incubated with $50 \mathrm{pM}{ }^{125}$ I-IGF-I (specific activity approximately 250 d.p.m./fmol) either with or without 50 nM IGF-I (Bachem UK Ltd) in buffer containing 0.2\% BSA and 1 $\mathrm{kIU}$ aprotinin $/ \mathrm{ml}$ at $4{ }^{\circ} \mathrm{C}$ for $24 \mathrm{~h}$. Sections were then washed in $50 \mathrm{mM}$ Tris- $\mathrm{HCl}(\mathrm{pH} 7 \cdot 4$ and containing
$5 \mathrm{mM} \mathrm{MgCl}$ ) for $15 \mathrm{~min}$ at $4{ }^{\circ} \mathrm{C}$, rinsed in distilled water and air-dried; X-AR OMAT film (Kodak, Rochester, NY, USA) was then exposed to the sections for 2 weeks. Approximately 30 pairs of hypothalamic and pituitary sections were used from each sheep.

\section{In situ hybridisation}

The in situ hybridisation procedure was performed as described previously, using single stranded 45-base oligonucleotide probes for IGF-I, IGF-II, IGF-1R, IGF-2R, IGFBP-1, IGFBP-2, IGFBP-3, IGFBP-4 and IGFBP-5 (Stevenson et al. 1994, Reynolds et al. 1997, Wathes et al. 1998, Osgerby et al. 1999). These probes have all been validated for use in tissues from the ewe. Briefly, sections were fixed in $4 \%$ paraformaldehyde in $0.01 \mathrm{M}$ PBS, washed in $0.01 \mathrm{M}$ PBS and dehydrated sequentially in 70 and 95\% ethanol. Antisense and sense oligonucleotide probes were ${ }^{35}$ S-labelled at the $3^{\prime}$-ends using terminal deoxynucleotidyl transferase (Pharmacia Biotechnology, St Albans, UK). Paired sections were hybridised with 110000 c.p.m. antisense or sense probe and incubated overnight at $42{ }^{\circ} \mathrm{C}$. After incubation, they were washed in saline sodium citrate $(1 \times \mathrm{SSC}) / 0 \cdot 2 \%$ sodium thiosulphate pentahydrate for $30 \mathrm{~min}$ at room temperature, then in $1 \times \mathrm{SSC} / 0 \cdot 2 \%$ sodium thiosulphate pentahydrate for $60 \mathrm{~min}$ at $55^{\circ} \mathrm{C}$. Finally, slides were rinsed for $1 \mathrm{~min}$ in each of the following: $1 \times$ SSC, $0 \cdot 1 \times$ SSC, $70 \%$ ethanol and $95 \%$ ethanol. Once dry, all slides were exposed to Hyperfilm- $\beta$-max (Amersham International plc, Amersham, Buckinghamshire, UK). Selected individual slides were subsequently dipped in photographic emulsion (LM1; Amersham International plc), stored at $4{ }^{\circ} \mathrm{C}$, then developed and counterstained with haematoxylin and eosin. For each probe, approximately 12 pairs of hypothalamic and pituitary sections were used from each sheep. Sections of ovine uterus and/or placenta, which had previously been shown to express the various components of the IGF system, were included within each batch of slides processed to provide positive controls.

\section{Western-ligand binding}

Anterior pituitary glands were collected from eight Suffolk $\times$ Greyface male castrate sheep that had received unrestricted food as part of another study (Adam et al. 1997b). The glands were dissected free of connective tissue and frozen glands were homogenised at a concentration of $100 \mathrm{mg}$ tissue per $\mathrm{ml}$ ice-cold SDS/cholate buffer, sonicated for $15 \mathrm{~s}$, and centrifuged at $13600 \mathrm{~g}$ for $10 \mathrm{~min}$ at $4{ }^{\circ} \mathrm{C}$ (after Funston et al. 1995a). The supernatant was removed, stored at $-80^{\circ} \mathrm{C}$, then subjected to SDSPAGE followed by Western-ligand blot analysis to determine the presence of IGFBPs (using the methods of Funston et al. 1995a, with minor adjustments). Bradford protein determinations were first carried out on the 
anterior pituitary homogenates; aliquots were then diluted to $50 \mu \mathrm{g}$ protein $/ 15 \mu \mathrm{l}$ homogenisation buffer before being mixed with $15 \mu \mathrm{l}$ gel loading buffer $(62.5 \mathrm{mM}$ Tris, $2 \%$ SDS, $0 \cdot 02 \%$ bromophenol blue, $10 \%$ glycerol, $\mathrm{pH} 6 \cdot 8$ ). Samples were boiled for $4 \mathrm{~min}$, placed on ice for 5-10 min, loaded into wells and electrophoresed through a 3\% stacking gel and a $12.5 \%$ separating gel in nonreducing conditions (Hossenlop et al. 1986). Protein molecular weight markers were electrophoresed at the same time in adjacent lanes. Separated proteins were electrophoretically transferred to a polyvinylidene difluoride membrane (Millipore) in transfer buffer $(25 \mathrm{mM}$ Tris, $192 \mathrm{mM}$ glycine in 15\% methanol), and IGFBP activity was detected by incubating membranes with ${ }^{125}$ I-IGF-I (after Lee et al. 1991). After electro-transfer, membranes were air-dried, incubated overnight at $4{ }^{\circ} \mathrm{C}$ in TBS (10 mM Tris ( $\mathrm{pH} 7 \cdot 4), 150 \mathrm{mM} \mathrm{NaCl}$ and $0.05 \%$ sodium azide) containing $1 \%$ polyvinylpyrrolidone (PVP40), washed in TBS for $2 \times 5 \mathrm{~min}$, then incubated in pairs at $4{ }^{\circ} \mathrm{C}$ with ${ }^{125}$ I-IGF-I (5000 000 c.p.m.) in TBS containing $0 \cdot 1 \%$ Tween-20 and $1 \%$ BSA. After incubation, membranes were washed for $2 \times 10 \mathrm{~min}$ in TBS containing $0 \cdot 1 \%$ Tween-20, then for $3 \times 10 \mathrm{~min}$ in TBS, before being air-dried; X-AR OMAT film (Kodak) was then exposed to the membranes at $4{ }^{\circ} \mathrm{C}$ for 2 weeks.

\section{Pituitary cell culture}

Pituitary glands were aseptically removed from abattoirkilled sheep (male castrates) during the breeding season and used for five culture experiment replicates $(n=3$ glands per culture). The anterior lobe was dissected out and the cells enzymatically dispersed and cultured as previously described (Ross et al. 1996). Cells were suspended at $5 \times 10^{5} / \mathrm{ml}$ in culture medium (Dulbecco's modified Eagle's medium (DMEM) containing 12.5\% lamb serum), plated at $0.5 \mathrm{ml}$ cell suspension per well in a 24-well plate and cultured at $37^{\circ} \mathrm{C}$. On Day 4 of culture, medium was discarded and plates were rinsed with serumfree medium. Cells were then cultured in $0.5 \mathrm{ml}$ fresh serum-free medium and challenged (six wells per treatment) with IGF-I (recombinant human, Bachem UK Ltd; $0 \cdot 1,1,10$ or $30 \mathrm{nM})$ or LHRH $(10 \mathrm{nM})$ alone or in combination (10 nM LHRH and $0 \cdot 1$ or $30 \mathrm{nM}$ IGF-I). Four hours after treatment, medium was collected, stored at $-20{ }^{\circ} \mathrm{C}$ and assayed for $\mathrm{LH}$.

\section{LH assay}

LH concentrations in culture medium were quantified by radioimmunoassay kit (National Institute of Digestive and Kidney Disorders (NIDDK), Rockville, MD, USA) in one assay run and expressed in terms of the reference standard NIDDK-oLH-1-2 (Adam et al. 1997a). The intra-assay coefficient of variation was $0 \cdot 13$ and the assay sensitivity was $0 \cdot 05 \mathrm{ng} / \mathrm{ml}$.
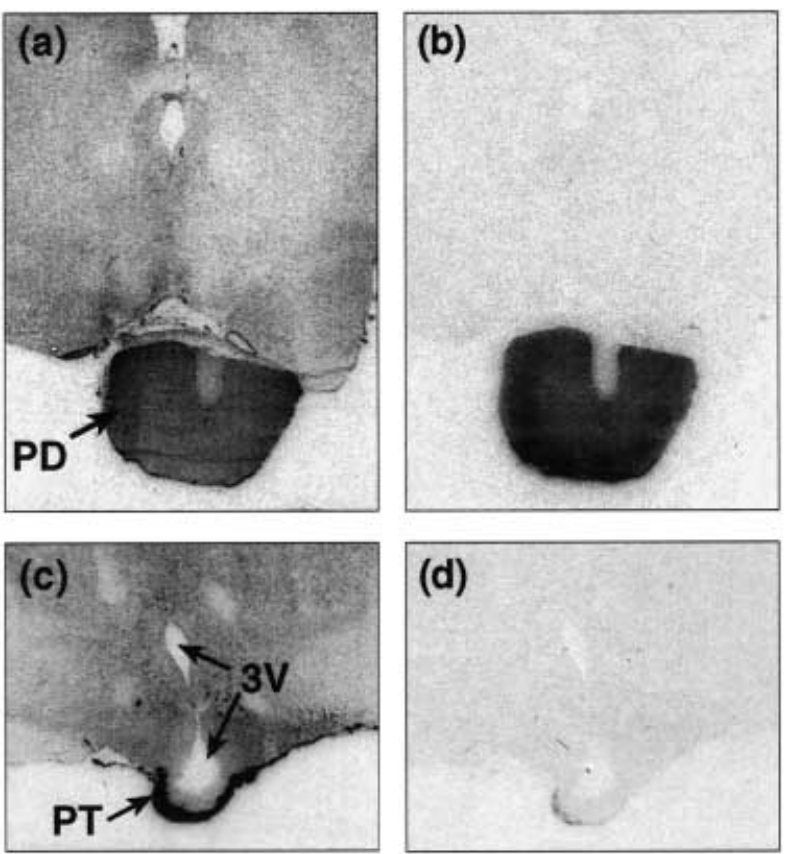

Figure $1{ }^{125}$ I-labelled IGF-I binding to coronal sections of ovine hypothalamus and pituitary in the absence $(\mathrm{a}, \mathrm{c})$ and presence (b, d) of 50 nM unlabelled IGF-I. PT, pars tuberalis; PD, pars distalis; $3 \mathrm{~V}$, third ventricle.

All chemicals were purchased from Sigma UK (Poole, Dorset, UK) unless otherwise stated.

\section{Statistical analysis}

LH concentrations in the five replicate pars distalis (PD) cell cultures following control, IGF-I and LHRH challenges were analysed by ANOVA (two-factor with replication) to determine significant treatment effects. Data (means and S.E.M values) were then transformed to express treatment effects as percentage stimulation of $\mathrm{LH}$ above the controls.

\section{Results}

In vitro autoradiography

Autoradiographic localisation revealed high concentrations of ${ }^{125}$ I-IGF-I binding in the pars tuberalis (PT) and PD of the pituitary, but less in the hypothalamus (Fig. 1). Binding in the PT but not the PD was displaced by excess unlabelled IGF-I.

In situ hybridisation

Large amounts of mRNA were detected for IGF-1R and IGFBP-5, localised to the PT and PD of the pituitary, and 


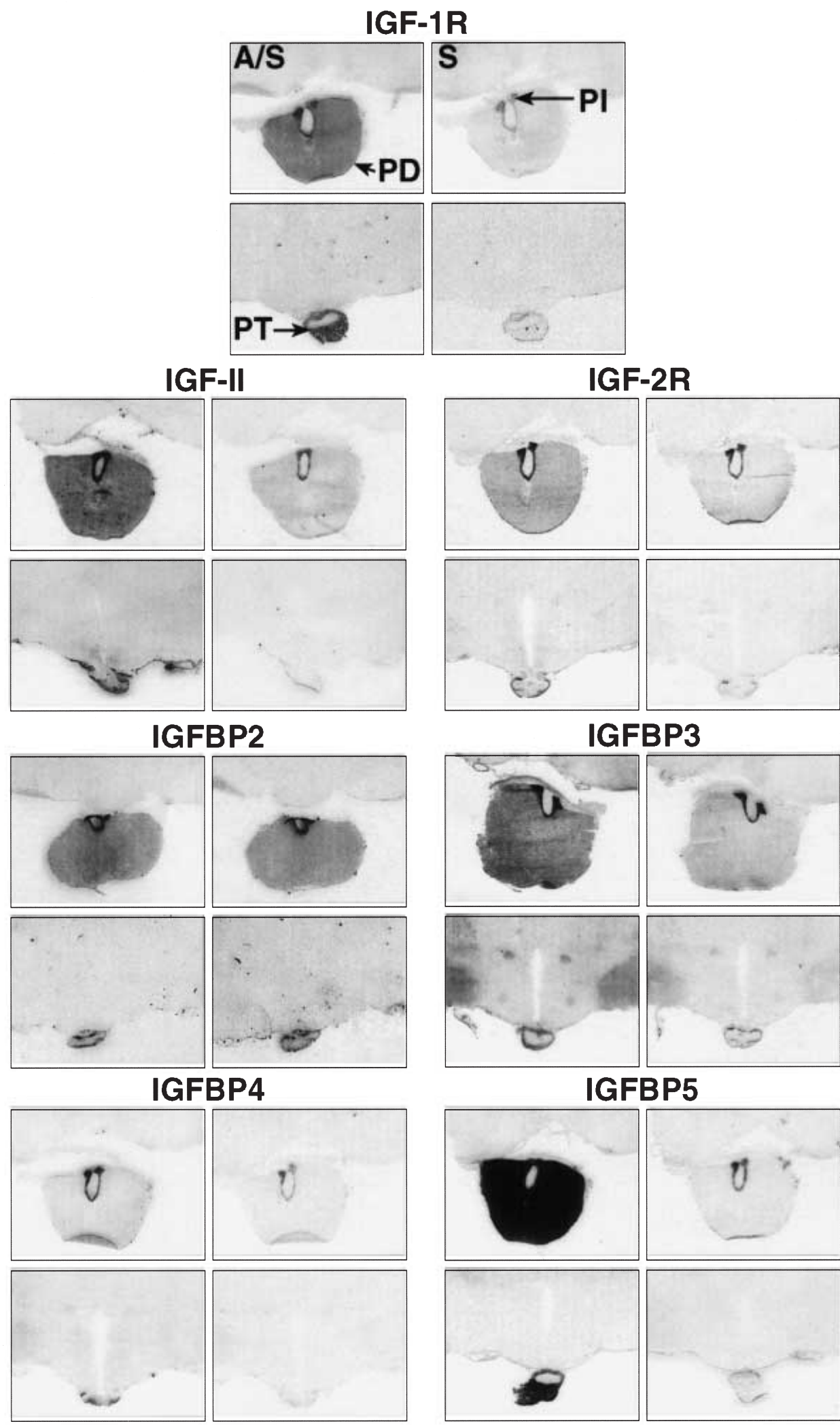



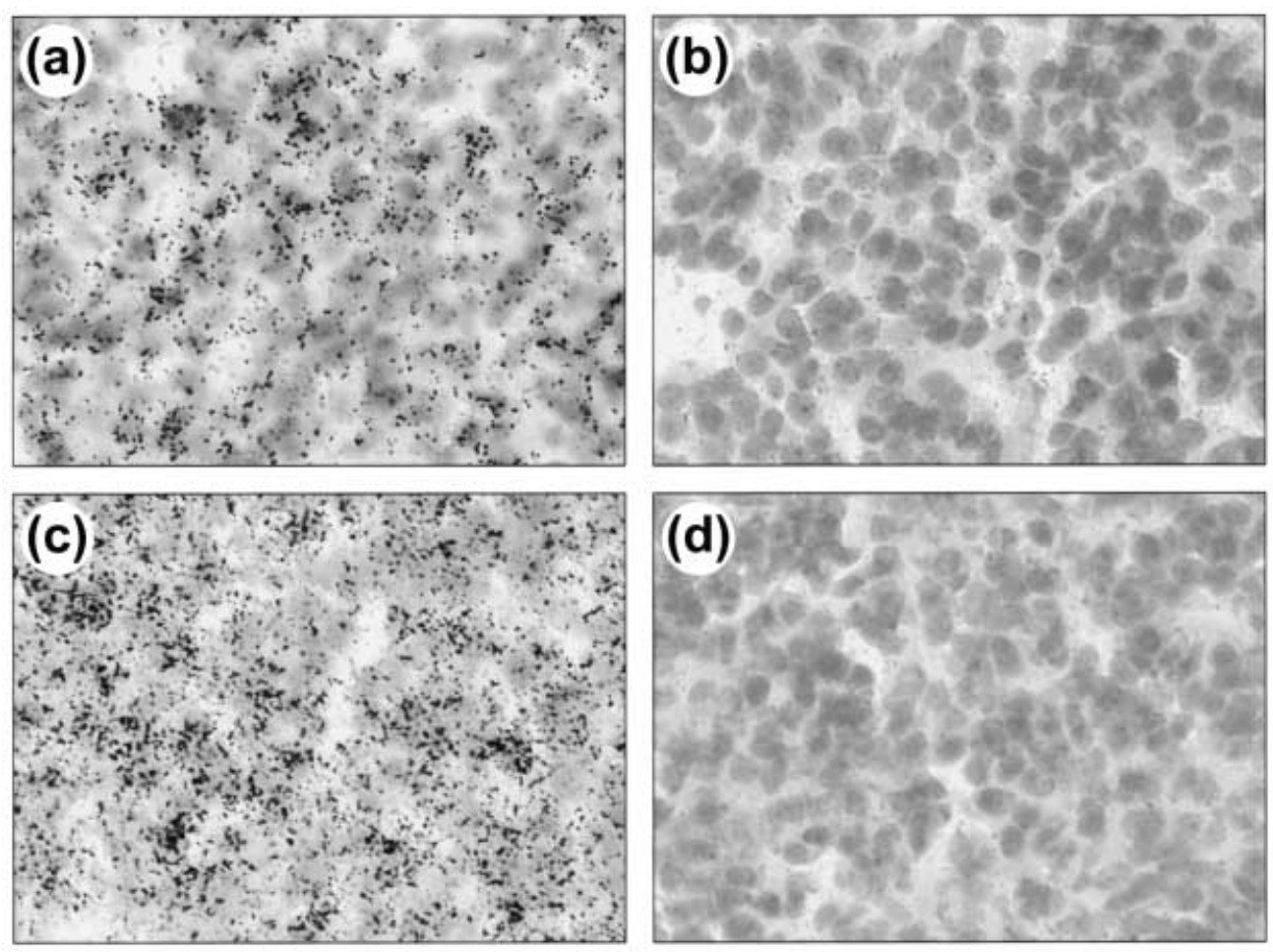

Figure 3 Photographic emulsions ( $\times 40$ magnification) of ovine pituitary (pars distalis) sections hybridised with antisense oligonucleotide probes to (a) IGF-1R mRNA and (c) IGFBP-5 mRNA; (b) and (d) show adjacent sections hybridised with corresponding sense probes.

less intense specific hybridisation signals were obtained with mRNAs for IGF-II, IGF-2R and IGFBP-3 localised to the same regions (Figs 2 and 3). IGFBP-4 mRNA gave a weak hybridisation signal in the PT but not in the PD. The specificity of hybridisation to the IGFBP-2 antisense probe was unproved since this was of similar intensity to that of the sense probe in PT and PD tissue. There was little evidence for specific hybridisation of any of the antisense probes to hypothalamic tissue. In all sections, the pars intermedia (PI) of the pituitary hybridised intensely and non-specifically with both sense and antisense probes. IGF-I and IGFBP-1 mRNAs were not detected in the hypothalamus or in the pituitary, although positive signals were found in the positive control sections of ovine uterus (data not shown).

\section{Western-ligand binding}

Proteins with ${ }^{125}$ I-IGF-I binding activity were detected in anterior pituitaries (Fig. 4) and identification was hypothesised according to their molecular weights (Hossenlop et al. 1986, Funston et al. 1995a,b, Jones \& Clemmons 1995). Binding was observed at approximately 36-40, 32 and $29 \mathrm{kDa}$ (identified as IGFBP-3, IGFBP-2 and IGFBP-5 respectively).

\section{Pituitary cell culture}

Relative to control treatments, $10(P>0 \cdot 05)$ and $30 \mathrm{nM}$ IGF-I $(P<0 \cdot 01)$ increased LH secretion in anterior pituitary cell cultures, but the lower concentrations of IGF-I had no effect (Fig. 5). LHRH stimulated LH release $(P<0 \cdot 001)$, with no additional effects from co-administered IGF-I.

\section{Discussion}

Intense ${ }^{125}$ I-IGF-I binding was localised in the pituitary tissue of the present sheep, with much less binding seen over the hypothalamic tissue, in agreement with the findings of Williams et al. (1995). High concentrations of

Figure 2 Autoradiographic localisation of mRNAs for IGF-1R, IGF-2R, IGFBP-2, -3, -4 and -5, and IGF-II following hybridisation of ovine hypothalamus and pituitary sections with antisense (A/S, left-hand side) or sense ( $\mathrm{S}$, right-hand side) oligonucleotide probes. PT, pars tuberalis; PD, pars distalis; PI, pars intermedia. 


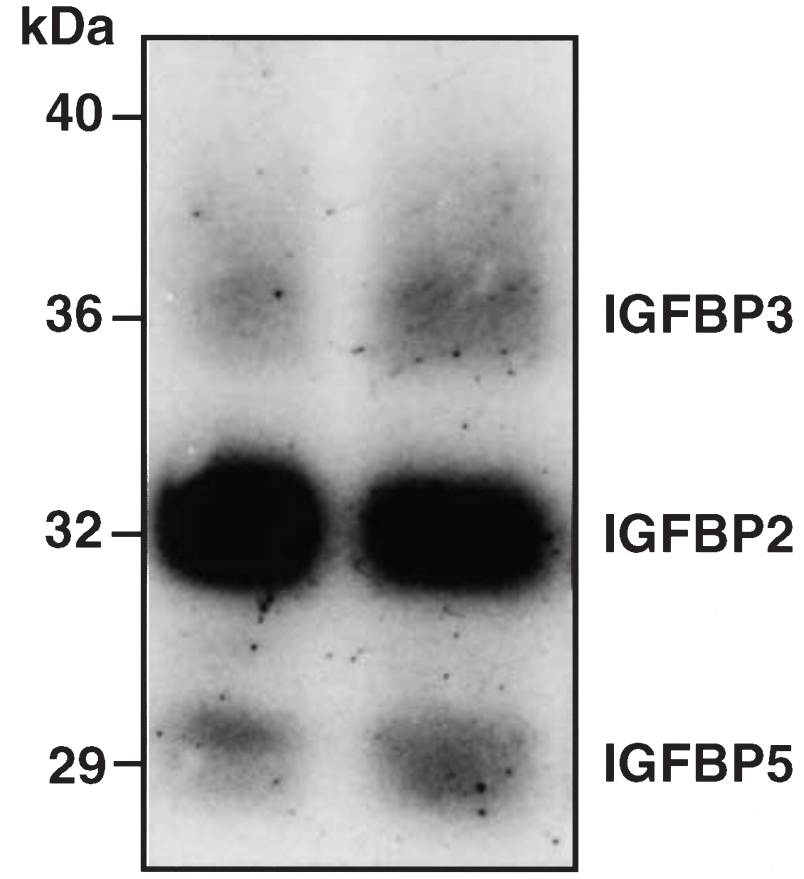

Figure 4 Ligand blot detection of IGFBPs in the anterior pituitary of two representative sheep. Identities of bands at 36-40, 32 and $29 \mathrm{kDa}$ were estimated from Funston et al. $(1995 a, b)$ as IGFBP-3, IGFBP-2 and IGFBP-5 respectively.

specific ${ }^{125}$ I-IGF-I binding in the PT were indicative of the presence of functional IGF-I receptors in this region, but the specificity of the intense binding seen in the PD was not confirmed by this method since it was not

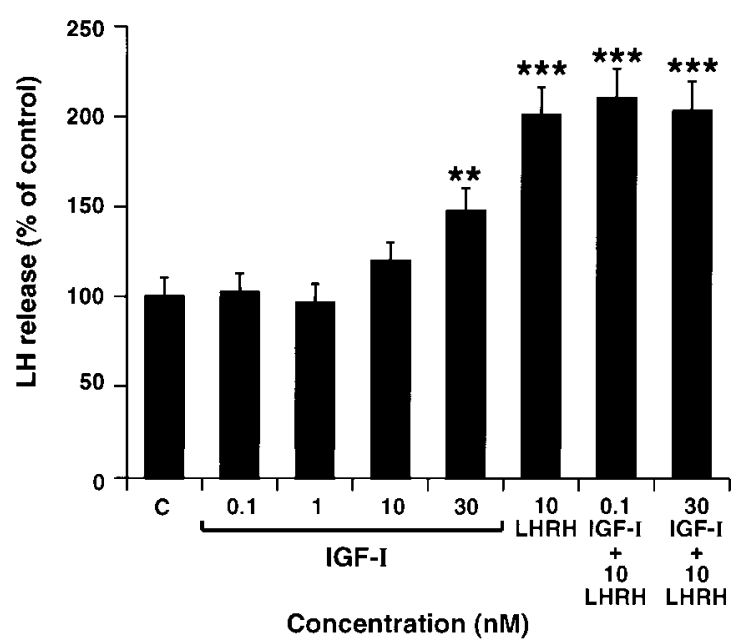

Figure 5 Effect of IGF-I and LHRH on LH release by cultured ovine anterior pituitary cells. Results from five replicate experiments, each with six wells per treatment $\left(2.5 \times 10^{5}\right.$ cells per well), are expressed as a percentage of basal LH release (mean value \pm S.E.M., $69 \cdot 9 \pm 5 \cdot 01 \mathrm{ng} / \mathrm{ml}$ ) in control cultures (C). ${ }^{* * *} P<0 \cdot 001,{ }^{* *} P<0 \cdot 01$ compared with $\mathrm{C}$. displaced by an excess of unlabelled IGF-I. This lack of displacement is a recurrent feature of ovine PD tissue (LM Williams, personal communication) and could have been attributable to the abundance of IGFBPs, the gene and/or peptide expression of which was localised in the same tissue. However, large amounts of IGF-1R mRNA, localised to the same pituitary PT and PD tissues, verified the probable abundant presence of the type-1 receptor. In the earlier study (Williams et al. 1995), the ${ }^{125}$ I-IGF-I binding over the PT appeared to represent a mixed population of functional IGF-I receptors and binding proteins; the present results now extend this observation to include the PD. ${ }^{125}$ I-IGF-I binding was not seen in the PI; the strong hybridisation signals, seen in this region, to the IGF receptor and IGFBP oligonucleotide probes were detected at similar intensities with both sense and antisense probes and were therefore non-specific. This was possibly attributable to the high density of melanotrophs in the PI, since similar non-specific binding has been reported in uterine melanocytes (Stevenson et al. 1994).

The low level of specific ${ }^{125}$ I-IGF-I binding seen throughout the hypothalamus was not accompanied by any IGF receptor or IGFBP mRNA in this region. This provided unconvincing evidence for endocrine actions of IGF-I within the hypothalamus compared with the overwhelming evidence for ${ }^{125}$ I-IGF-I binding, IGF receptor and IGFBP gene expression in pituitary tissue. The ${ }^{125}$ I-IGF-I was possibly binding in the hypothalamus to insulin receptors, which are widespread in the brain and have some affinity for IGF-I (Schwartz et al. 1992).

Although mRNA for the type-2 receptor was also detected in PT and PD tissues, this receptor does not bind IGF-I (Kornfeld 1992), and its presence could be to act as a clearance receptor for IGF-II (Baker et al. 1993) since IGF-II mRNA was localised in the same tissues. The function of this putative intrapituitary paracrine/autocrine role for IGF-II is unknown.

The present data demonstrate the presence in ovine PT and PD pituitary tissue of gene expression for IGFBP-3 and IGFBP -5 but not IGFBP-2. In addition, IGFBP-2, -3 and -5 peptides were detected by Western-ligand blotting in ovine anterior pituitaries, as previously reported for both ovine and bovine anterior pituitaries (Funston et al. 1995a,b; Snyder et al. 1999). This would suggest that the IGFBP-2 peptide in pituitary tissue is synthesised elsewhere; indeed, IGFBP-2 is found in circulating blood (Funston et al. 1995a,b). It is acknowledged that the relative amounts of IGFBP gene and peptide expression (examined here in luteal-phase ewes and male castrates respectively) may vary with reproductive status, since anterior pituitary IGFBP-2 is apparently increased by oestradiol in ewes (Clapper et al. 1998), and the relative amounts of the anterior pituitary IGFBPs vary with stage of the oestrous cycle in cows (Funston et al. 1995a). The precise functions of IGF binding proteins within the pituitary have yet to be elucidated but are likely to involve 
modulation of IGF actions (Jones \& Clemmons 1995). They are apparently nutritionally sensitive, in that changes in the amount of IGFBPs are seen in the serum and hypothalamo-pituitary tracts of thin ewes with low circulating IGF-I relative to fatter ewes (Snyder et al. 1999). In summary, the presence of IGFBPs with the same localisation as IGF-1R is consistent with the intrapituitary nutritional feedback actions of IGF-I.

IGF-I actions within the ovine PT have previously been demonstrated in short-term cultures by its ability to regulate mitogen-activated protein kinase (Hazlerigg et al. 1996). Its precise physiological role in the PT is still open to speculation but the presence of gene expression for components of an IGF system, in addition to the specific ${ }^{125}$ I-IGF-I binding, lends support to its significance.

Since gene expression for IGF-I itself was not detected in the present ovine pituitaries, the intrapituitary actions of IGF-I are likely to be endocrine rather than paracrine/ autocrine. From photographic emulsion-coated sections, it could be seen that the most abundant mRNAs (IGF-IR and IGFBP-5) were homogeneously and abundantly distributed throughout the anterior pituitary, which is compatible with their expression by endocrine cells (Fig. 3). Clearly, the endocrine role of IGF-I in the ovine anterior pituitary is likely to include actions on other cell types, such as somatotrophs (Fletcher et al. 1995), but putative actions on gonadotrophin secretion were the focus of the present study.

Given that pituitary cells apparently had the machinery to respond to circulating IGF-I, the final evidence supporting our hypothesis was the demonstration that physiological concentrations of IGF-I stimulated LH release from cultured ovine pituitary cells. This effect was dose-dependent, as in eel pituitary cell cultures (Huang et al. 1998). LHRH alone provided greater LH stimulation and was unaffected by IGF-I co-administration. This suggested that the present actions of IGF-I on LH were direct rather than via enhanced LHRH-induced LH release, in contrast to the evidence for both mechanisms from rat pituitary cell culture data (Soldani et al. 1994, 1995). The stimulatory dose of IGF-I alone in vitro $(30 \mathrm{nM})$ approximates to plasma concentrations in pubertal sheep (CL Adam \& PA Findlay 1997, unpublished observations) and is therefore in the physiological range. However, the LHRH dose used in this experiment was probably excessive, producing maximal $\mathrm{LH}$ release, and it is acknowledged that different relative concentrations of IGF-I and LHRH may have produced different responses.

The available evidence points to IGF-I acting as a circulating messenger that can mediate nutritional effects on gonadotrophin secretion in sheep. The present findings are consistent with this action being at the level of the pituitary gland rather than the hypothalamus, unlike the rat model (Hiney et al. 1996), but in agreement with its site of feedback actions on ovine growth hormone secretion (Fletcher et al. 1995). Accordingly, IGF-I concentrations in the cerebrospinal fluid of sheep during nutritional stimulation of gonadotrophin secretion were not elevated despite concomitantly raised concentrations in plasma (Miller et al. 1998), and IGF-I administered intracerebroventricularly to sheep had no effect on pulsatile LH secretion (L Chagas, D Blache \& GB Martin, personal communication). Although the major focus of research into nutritional modulation of the gonadotrophic axis in the past has addressed actions at the hypothalamic level (e.g. Miller et al. 1998), it is now clear that actions at the pituitary provide further control. Since the precise regulation of gonadotrophin secretion is vital to reproductive function, it is perhaps not surprising that this should be achieved by the interaction of components at both the pituitary and hypothalamic level (Evans 1999).

In summary, the present data demonstrate the existence of an intrapituitary IGF system in the sheep and provide evidence consistent with an endocrine role for IGF-I in nutritional modulation of $\mathrm{LH}$ secretion at the level of the pituitary gland.

\section{Acknowledgements}

We thank NIDDK for the ovine LH RIA kit, T Atkinson (Rowett Research Institute) for iodinating the LH trace, C Webster (Rowett Research Institute) for assistance with the pituitary cell cultures, and G Zuur (Biomathematics \& Statistics Scotland) for statistical advice. This research was supported by the Scottish Executive Rural Affairs Department (Rowett Research Institute) and The Wellcome Trust (Royal Veterinary College).

\section{References}

Adam CL \& Findlay PA 1997 Effect of nutrition on testicular growth and patterns of gonadotrophin, testosterone and IGF-I concentrations in plasma of pubertal male Soay sheep. Journal of Reproduction and Fertility 111 121-125.

Adam CL, Kyle CE, Young P \& Atkinson T 1995 Effect of nutritional growth restriction on timing of reproductive development and plasma concentrations of insulin-like growth factor-1 and growth hormone in male red deer (Cervus elaphus) reared in constant photoperiod. Animal Science 61 155-160.

Adam CL, Findlay PA \& Hotston Moore A 1997a Effects of insulin-like growth factor-1 on luteinizing hormone secretion in sheep. Animal Reproduction Science 50 45-56.

Adam CL, Findlay PA, Kyle CE, Young P \& Mercer JG 19976 Effect of chronic food restriction on pulsatile luteinizing hormone secretion and hypothalamic neuropeptide $\mathrm{Y}$ gene expression in castrate male sheep. Journal of Endocrinology 152 329-337.

Adam CL, Findlay PA, Kyle CE \& Young P 1998 Effect of restricted nutrition on the timing of puberty in female Soay sheep. Journal of Reproduction and Fertility 112 31-37.

Baker J, Lui J-P, Robertson EJ \& Efstratiadis A 1993 Role of insulin-like growth factors in embryonic and postnatal growth. Cell $7573-82$. 
Clapper JA, Snyder JL, Roberts AJ, Hamernik DL \& Moss GE 1998 Estradiol increases relative amounts of insulin-like growth factor binding protein (IGFBP)-3 in serum and expression of IGFBP-2 in anterior pituitaries of ewes. Biology of Reproduction 59 $124-130$.

Evans JJ 1999 Modulation of gonadotropin levels by peptides acting at the anterior pituitary gland. Endocrine Reviews 20 46-67.

Fletcher TP, Thomas GB, Dunshea FR, Moore LG \& Clarke IJ 1995 IGF feedback effects on growth hormone secretion in ewes: evidence for action at the pituitary but not the hypothalamic level. Journal of Endocrinology 144 323-331.

Funston RN, Moss GE \& Roberts AJ 1995a Insulin-like growth factor I and insulin-like growth factor binding proteins in bovine sera and pituitaries at different stages of the estrous cycle. Endocrinology 136 62-68

Funston RN, Roberts AJ, Hixon DL, Hallford DM, Sanson DW \& Moss GE $1995 b$ Effect of acute glucose antagonism on hypophyseal hormones and concentrations of insulin-like growth factor (IGF)-I and IGF-binding proteins in serum, anterior pituitary, and hypothalamus of ewes. Biology of Reproduction 52 1179-1186.

Handelsman DJ, Spaliviero JA, Scott CD \& Baxter RC 1987 Hormonal regulation of the peripubertal surge of insulin-like growth factor-1 in the rat. Endocrinology 120 491-496.

Hazlerigg DG, Thompson M, Hastings MH, \& Morgan PJ 1996 Regulation of mitogen-activated protein kinase in the pars tuberalis of the ovine pituitary: interactions between melatonin, insulin-like growth factor-1, and forskolin. Endocrinology 137 210-218.

Hiney JK, Srivastava V, Nyberg CL, Ojeda SR \& Dees WL 1996 Insulin-like growth factor 1 of peripheral origin acts centrally to accelerate the initiation of female puberty. Endocrinology 137 $3717-3728$.

Hossenlop P, Seurin D, Segovia-Quinson B, Hardouin S \& Binoux M 1986 Analysis of serum insulin-like growth factor binding proteins using Western blotting: use of the method for titration of the binding proteins and competitive binding studies. Analytical Biochemistry 154 138-143.

Huang Y-S, Rousseau, Le Belle N, Vidal B, Burzawa-Gerard E, Marchelidon J \& Dufour S 1998 Insulin-like growth factor-I stimulates gonadotrophin production from eel pituitary cells: a possible metabolic signal for induction of puberty. Journal of Endocrinology 159 43-52.

Jones JI \& Clemmons DR 1995 Insulin-like growth factors and their binding proteins: biological actions Endocrine Reviews 16 3-34.

Kornfeld S 1992 Structure and function of the mannose 6-phosphate/insulin-like growth factor 2 receptors. Annual Reviews of Biochemistry 61 307-330.

Lee CY, Bazer FW, Etherton TD \& Simmen FA 1991 Ontogeny of insulin-like growth factors (IGF-I and IGF-II) and IGF-binding proteins in porcine serum during fetal and postnatal development. Endocrinology 1991128 2336-2344.

LeRoith D, Werner H, Beiter-Johnson D \& Roberts CT 1995 Molecular and cellular aspects of the insulin-like growth factor 1 receptor. Endocrine Reviews 16 143-163.

Mauras N, Rogol AD, Haymond MW \& Veldhuis JD 1996 Sex steroids, growth hormone, insulin-like growth factor-1: neuroendocrine and metabolic regulation in puberty. Hormone Research 45 74-80.
Miller DM, Blache D, Boukhliq R, Curlewis JD \& Martin GB 1998 Central metabolic messengers and the effects of nutrition on gonadotrophin secretion in sheep. Journal of Reproduction and Fertility 112 347-356.

Osgerby JC, Gadd TS \& Wathes DC 1999 Expression of insulin-like growth factor binding protein-1 (IGFBP-1) mRNA in the ovine uterus throughout the oestrous cycle and early pregnancy. Journal of Endocrinology 162 279-287.

Reynolds TS, Stevenson KR \& Wathes DC 1997 Pregnancy-specific alterations in the expression of the insulin-like growth factor system during early placental development in the ewe. Endocrinology 138 886-897.

Ross AW, Barrett P, Mercer JG \& Morgan PJ 1996 Melatonin suppresses the induction of AP-1 transcription factor components in the pars tuberalis of the pituitary. Molecular and Cellular Endocrinology 123 71-80.

Schwartz MW, Figlewicz DP, Baskin DG, Woods SC \& Porte D 1992 Insulin in the brain: a hormonal regulator of energy balance. Endocrine Reviews 13 387-414.

Snyder JL, Clapper JA, Roberts AJ, Sanson DW, Hamernik DL \& Moss GE 1999 Insulin-like growth factor-I, insulin-like growth factor-binding proteins, and gonadotropins in the hypothalamicpituitary axis and serum of nutrient-restricted ewes. Biology of Reproduction 61 219-224.

Soldani R, Cagnacci A \& Yen SSC 1994 Insulin, insulin-like growth factor I (IGF-I) and IGF-II enhance basal and gonadotrophinreleasing hormone-stimulated luteinizing hormone release from rat anterior pituitary cells in vitro. European Journal of Endocrinology 131 641-645.

Soldani R, Yen SSC, Cagnacci A, Melis GB \& Paoletti AM 1995 Modulation of anterior pituitary luteinizing hormone response to gonadotropin-releasing hormone by insulin-like growth factor I in vitro. Fertility and Sterility 64 634-637.

Stevenson KR, Gilmour RS \& Wathes DC 1994 Localization of insulin-like growth factor-I (IGF-I) and -II messenger ribonucleic acid and type 1 IGF receptors in the ovine uterus during the estrous cycle and early pregnancy. Endocrinology 134 1655-1664.

Wathes DC, Reynolds TS, Robinson RS \& Stevenson KR 1998 Role of the insulin-like growth factor system in uterine function and placental development in ruminants. Journal of Dairy Science $\mathbf{8 1}$ 1778-1789.

Whitley NC, Barb CR, Utley RV, Popwell JM, Kraeling RR \& Rampacek GB 1995 Influence of stage of the estrous cycle on insulin-like growth factor-1 modulation of luteinizing hormone secretion in the gilt. Biology of Reproduction 53 1359-1364.

Williams LM, Kelly D, Hannah LT \& Morgan PJ 1995 Localization of $\left[{ }^{125} \mathrm{I}\right] \mathrm{IGF}-1$ binding on the ovine pars tuberalis. Journal of Neuroendocrinology 7 931-938.

Wilson ME 1998 Premature elevation in serum insulin-like growth factor-I advances first ovulation in rhesus monkeys. Journal of Endocrinology 158 247-257.

Received 28 July 1999

Revised manuscript received 20 March 2000 Accepted 11 April 2000 